IZA DP No. 8222

Educational Policies and Income Inequality

Daniele Checchi

Herman G. van de Werfhorst

May 2014 


\title{
Educational Policies and Income Inequality
}

\author{
Daniele Checchi \\ University of Milan \\ and IZA \\ Herman G. van de Werfhorst \\ University of Amsterdam
}

Discussion Paper No. 8222

May 2014

IZA

P.O. Box 7240

53072 Bonn

Germany

Phone: +49-228-3894-0

Fax: +49-228-3894-180

E-mail: iza@iza.org

Any opinions expressed here are those of the author(s) and not those of IZA. Research published in this series may include views on policy, but the institute itself takes no institutional policy positions. The IZA research network is committed to the IZA Guiding Principles of Research Integrity.

The Institute for the Study of Labor (IZA) in Bonn is a local and virtual international research center and a place of communication between science, politics and business. IZA is an independent nonprofit organization supported by Deutsche Post Foundation. The center is associated with the University of Bonn and offers a stimulating research environment through its international network, workshops and conferences, data service, project support, research visits and doctoral program. IZA engages in (i) original and internationally competitive research in all fields of labor economics, (ii) development of policy concepts, and (iii) dissemination of research results and concepts to the interested public.

IZA Discussion Papers often represent preliminary work and are circulated to encourage discussion. Citation of such a paper should account for its provisional character. A revised version may be available directly from the author. 


\section{ABSTRACT}

\section{Educational Policies and Income Inequality}

In this paper we study the associations between educational policies, distributions of educational attainments and income distributions. By matching inequality measures on test scores, years of education and labour earnings by country, birth cohorts and gender, we show that inequality in education (measured both at quality and quantity levels) affect earnings inequality. We then consider potential endogeneity of educational distributions and we resort to instrumental estimation using information on government reforming activity in the field of education. By controlling for country-specific and time fixed effects, and by separating age and cohorts effects, we prove that educational inequality respond to educational reforms, identifying educational policies (like later entry into compulsory education or introduction of standardised tests) capable to reduce income inequalities thirty years later.

JEL Classification: $\quad 124,128$

Keywords: educational inequality, test score, earnings inequality, educational policies

Corresponding author:

Daniele Checchi

Department of Economics

University of Milan

via Conservatorio 7

20122 Milano

Italy

E-mail: daniele.checchi@unimi.it 


\section{Introduction}

Thanks to the abundant availability of comparative data on student achievement, we have come to know a lot about the association between characteristics of educational systems and student learning. Student achievement tests like the Programme of International Student Assessment (PISA), the Trends in International Mathematics and Science Study (TIMSS) and the Programme for International Reading and Literacy Study (PIRLS) have helped us to understand whether educational policies are related to the distribution of student performance, and inequality in performance by social and ethnic background (Hanushek and Wössmann 2011; Kerckhoff 1995; Van de Werfhorst and Mijs 2010; Brunello and Checchi 2007; Marks 2005; Cobb-Clark et al. 2012). Educational policies that received attention include, among others, tracking, accountability regulations, and length of compulsory schooling.

However, there are three shortcomings in the present literature. First, most of the studies have looked at educational policies in a static way, whereas policies in fact change over time within countries. Given the cross-sectional nature of the comparative datasets the cross-sectional focus is understandable, but to assess whether policies affect outcomes (in a causal meaning) one would also want to exploit within-country temporal variations. Second, the literature has mostly concentrated on student achievement at a relatively young age (mostly students aged between 8 and 15). Other outcomes in educational distributions, most notably the attained level of education, has received far less attention from a policy perspective. In other words, most attention has been paid to the 'quality' of education rather than its 'quantity'. This is unfortunate, because we do not know whether policies that are related to the quality of education are also related to the quantity of schooling in societies. Thirdly, studies focusing on educational policy have mostly addressed educational outcomes. It is heavily understudied whether educational policies have, through their effects on educational distributions, also repercussions on income and earnings distributions in societies. In our view it is crucial to understand whether policies affect educational and income distributions, because the effectiveness of educational systems may be assessed not only in terms of the skills and qualifications that are produced, but also in terms of the stratification in society that is generated through educational policies. After all, educational policy is often geared towards preparing youth for adult life, so to understand whether this preparation is successful one needs to study distributions in earnings and income in addition to distributions in educational outcomes.

In this paper we contribute to understanding the associations between educational policies, educational distributions and income distributions by combining four sorts of data. First, as a starting point we have exploited comparative mathematics achievement data from various years: the First International Mathematics Study of 1964 (FIMS64), the Second International Mathematics 
Study of 1980-1982 (SIMS80), and the Trends in International Mathematics and Science Study of 1995 (TIMSS95). This collection provides us with mathematics achievement data, as indicator of the 'quality' of education, for a multitude of cohorts and countries, split out by gender. Second, for the cohorts and countries for which data were available in these student achievement tests, we have collected data on educational policies, including policies on compulsory education, school and/or teachers' autonomy, and tracking age (see Braga et al. 2013). Third, using data from Eurostat, we have collected data on educational attainments measured by the (median) years of schooling required to attain a specific degree, following the ISCED classification. This is again done for each combination of cohort, country and gender separately. Fourth, for each combination of country, cohort and gender we have calculated income inequalities using the European Community Household Panel (ECHP) and the European Union Statistics on Income and Living Conditions (EUSILC), the latter being official European Union data on income statistics.

These four data sources enable us to study whether educational policies are related to the distribution of quality and quantity of education, and whether policies and educational distributions (of both quality and quantity) are related to income inequality. By controlling for country-specific and time fixed effects, and by separating age and cohorts effects, we believe that our assessment of policy effects is stronger than in most other studies. Our results indicate that inequality in education (measured both at quality and quantity levels) affect earnings inequality. In addition, since educational inequality respond to educational reforms, we are able to identify educational policies (like later entry into compulsory education or introduction of standardised tests) capable to reduce income inequalities thirty years later.

\section{Policies, education and income distributions}

\section{Educational policy and educational outcomes}

The wealth of data, and the improved statistical knowledge to analyze them, has led to a great number of studies on inequality of educational opportunity in relation to characteristics of educational systems. Much of the literature has been reviewed elsewhere (Hanushek and Wössmann 2011; Van de Werfhorst and Mijs 2010). Two different forms of inequality have been addressed: inequality as dispersion (i.e. within-country variance in student test scores), and inequality of educational opportunity (i.e. the association between social or ethnic origin and student test scores in a given country). These are two distinct forms of inequality, as a limited dispersion could coincide with a rigorous placement on the achievement scales based on social origin; or a wide dispersion could coincide with limited effects of social origin on where in the distribution a student would be placed. Yet, in practice the two are related (Duru-Bellat and Suchaut 2005). 
Figure 1 shows the two forms of inequality with regard to mathematics achievement, using the Trends in International Mathematics and Science Study of 2011 (TIMSS 2011, grade 8) and the OECD’s Programme for International Student Assessment of 2009 (PISA 2009, 15-year olds). Inequality as dispersion is measured by the standard deviation in mathematics achievement. Inequality of opportunity is measured by the effect of the number of books in the household (a useful indicator of social background, Schütz et al. 2008) on mathematics achievement. Books in the household are measured as the within-country proportional score, ranging from $0-1$, and mathematics is measured using a factor score on five plausible values. Figure 1 shows a positive association between the two forms of inequality. Countries with larger dispersions have, on average, also a stronger relationship between social background and student achievement. At the country level, the two forms of inequality are correlated at $\rho=0.7$, in both datasets.

Figure 1: Inequality as dispersion and inequality of opportunities
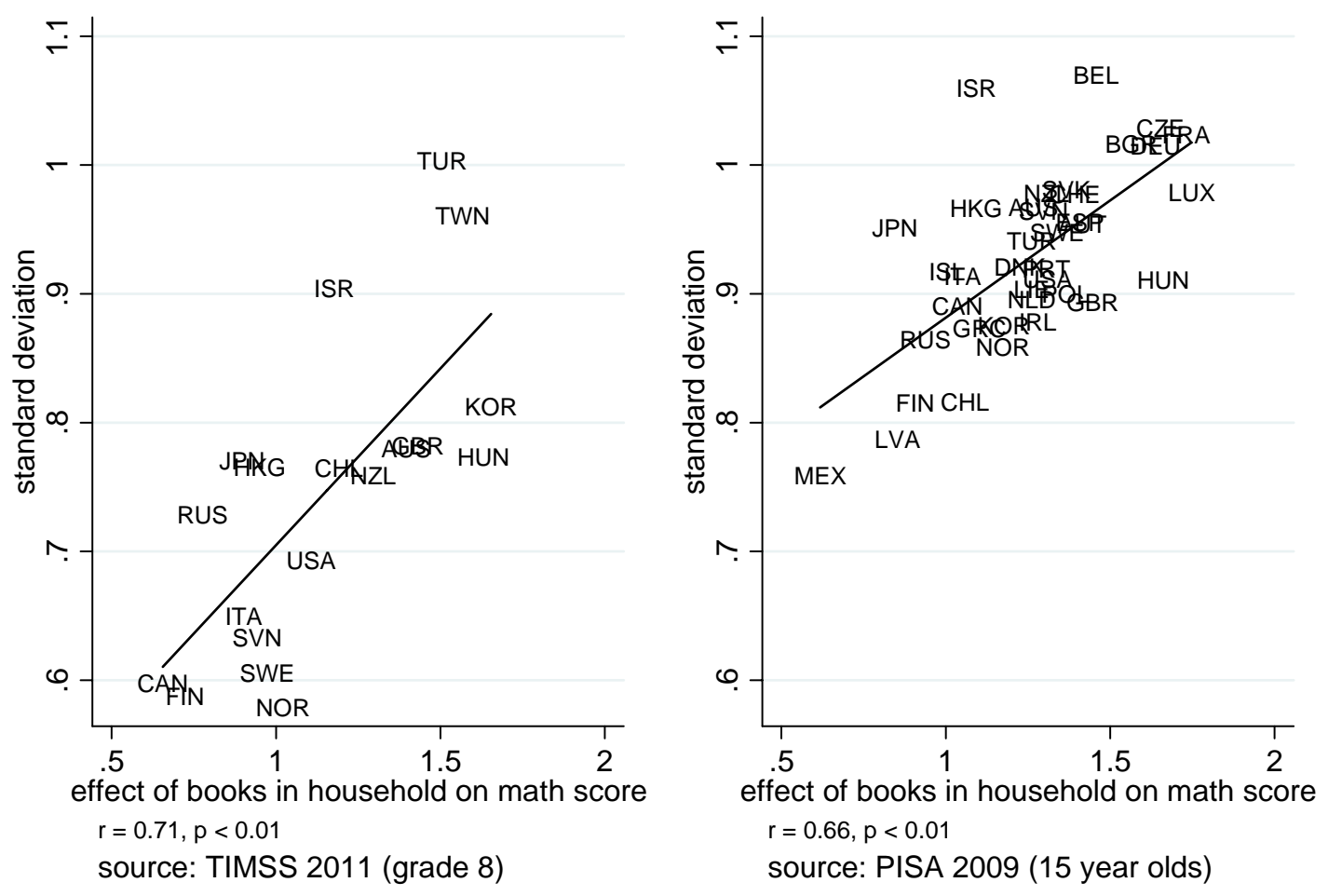

The level of inequality in a school system seems to be related to the educational institutional structure in a society. Earlier research has focused on several indicators of educational systems, including early tracking, school accountability, the usage of centralized tests, the existence of (public) early childhood education, and the size of the private sector.

One of the main factors related to inequality is the extent to which, and at which moment, students are tracked in different educational trajectories. Early selection in the educational system is 
known to be associated to higher levels of inequality in student test scores and educational attainment by social origin (Bol and Van de Werfhorst 2013; Brunello and Checchi 2007; Horn 2009; Husén 1973; Marks 2005; Pfeffer 2008; Schütz et al. 2008). Also ethnic inequalities are larger in early tracking systems than in comprehensive systems (Cobb-Clark et al. 2012; Entorf and Lauk 2008, but see Dronkers and De Heus 2010). More strongly differentiated systems are also associated to more realistic expectations of students concerning future educational attainment (Buchmann and Dalton 2002; Buchmann and Park 2009; Kerckhoff 1977), which may explain the relatively early formation of political interests (Koçer and Van de Werfhorst 2012). Importantly, especially early tracking, and not so much the vocational sector in upper secondary education, is related to larger inequalities of opportunity (Brunello and Checchi 2007; Bol and Van de Werfhorst 2013). A strong vocational sector in the education system functions rather inclusionary rather than diverging (cf. Arum and Shavit 1995; Shavit and Müller 2000).

The evidence on the relationship between early differentiation/tracking and inequality as dispersion is more mixed. Some have reported higher dispersions in countries with more intensified forms of between-school differentiation/tracking (Hanushek and Wössmann 2005; Huang 2009; Montt 2011), whereas findings of other studies do not point in that direction (Vandenberge 2006; Micklewright and Schnepf 2007).

The evidence is also more mixed with regard to the relationship between other characteristics of educational systems and inequalities. The size of the private schooling sector has been found to be uncorrelated to the level of inequality by social origin (Pfeffer 2008; Bol and Van de Werfhorst 2013). School accountability is associated to lower inequalities in student achievement by parental education (Wössmann 2005). Lower levels of ethnic inequality are found in systems with an earlier starting age of compulsory education (Cobb-Clark et al. 2012), with centralized examinations, and a small private schooling sector (Cobb-Clark et al. 2012; Wössmann 2005). Larger private contributions to early childhood education exacerbate income inequalities between families, which may impact unequal take-up and benefit from it (Meyers and Gornick 2003). But more generally Hanushek and Wössmann (2011) conclude that country characteristics related to resources have limited effects on student learning, whereas other institutional effects relating to the structure of schools have stronger impacts.

\section{Educational distributions and income distributions}

The relationship between education and earnings has a long tradition in the economic and sociological literature (see Card 1999 and Heckman et al. 2006 for reviews of the Mincerian approach). Less attention has been devoted to the relationship between the distribution of 
educational attainments and the distribution of earnings (see Peracchi 2006, De Gregorio and Lee 2002 and Rodriguez-Pose and Selios 2009 for notable exceptions), possibly because the difficulty of identifying clear causal links between the two, given the presence of unobservables. An increase in earnings inequality may prevent educational investments when households are liquidity constrained (Galor 2012), but may also represent an incentive to acquire further education. General equilibrium models should account for the relative speeds of expansion of demand and supply for skills (the so-called "Timbergen race”: see Acemoglu and Autor 2011; Goldin and Katz 2009).

More recently, some studies have investigated the relationship between the distribution of education distinguishing between quantity (typically measured by the years of schooling) and quality of educational attainments (measured by level of competences). In particular, the educational endowment (call it human capital for simplicity) can be considered as consisting in two dimensions: quantity (years of education $h$ ) and quality (competences $q$ ). In accordance with most of the theoretical and empirical literature, earnings $y$ are assumed to be correlated with total human capital along these two dimensions. If we make the further assumption that quantity and quality interact in the production of human capital as imperfect substitutes, we may write

$$
y=f(h, q), f_{h}^{\prime}>0, f_{q}^{\prime}>0, f_{h q}^{\prime \prime} \geq 0
$$

Consequently, inequality in earnings depends on the distribution of years of education and of competences, as well as on their covariance. Assuming for (1) a standard Cobb-Douglas formulation one can write

$$
y=A h^{\alpha} q^{\beta}
$$

which can then be re-expressed in log-linear terms, with $\alpha$ and $\beta$ indicating the earnings elasticity wrt quantity and quality of education, respectively. If information about cognitive skills of the interviewee is available, it is then possible to estimate an augmented Mincerian wage function of the type

$$
\log \left(y_{i j}\right)=a_{j}+\alpha_{j} \log \left(h_{i}\right)+\beta_{j} \log \left(q_{i}\right)+\varepsilon_{i j}
$$


where $i$ indicates the individual and $j$ a specific labour market (typically a country/region). Equation (3) has been estimated by Blau and Kahn (2005) using micro-data from IALS. ${ }^{1}$ They claim that the greater dispersion of cognitive test scores in the United States plays a part in explaining higher U.S. wage inequality. The estimated $\hat{\alpha}$ and $\hat{\beta}$ give us an idea of the relative contribution of quantity and quality of education in generating income inequality. ${ }^{2}$ In the same vein, using the Canadian file of the same survey, Green and Riddell (2003) estimate a linear polynomial version of equation (3), showing that the impact of literacy on earnings does not vary across quantiles of the earnings distribution, while the interaction of schooling and literacy is statistically insignificant. This result can be interpreted as a signal that competences provide an autonomous contribution to observed inequality, conditional on identical school attainment. Freeman and Schettkat (2001) follow a parallel approach when comparing US and Germany earnings inequality, by comparing the distribution of earnings at different points of the distribution of competences in the adult population using the same IALS survey. They show that US is characterised by greater inequality in competences than Germany, which is reflected into greater inequality in earnings, and they attribute this difference to both the educational system (the German apprenticeship system would raise the bottom of the competence distribution) and the bargaining structure (Germany is characterised by stronger union movement than US). Also a more recent study has found a crosssectional correlation between a country's level of inequality in adult skills (using PIAAC 2012 data) and income inequality (Solga 2014).

The main problem of this research strategy is the potential endogeneity of the right-hand side regressors, since more talented individuals may possess higher level of competences (as well as achieve higher educational attainments) while obtaining higher earnings. In the absence of credible instruments, it is hard to accept a causal interpretation of previous results. In addition, competences are typically measured at the very same time when information on earnings is collected (cf. Solga 2014). But competences are (positively) correlated with educational attainment as well as with labour market participation, thus requiring an appropriate modelling of the self-selection into the labour market.

Ideally, one would require a dataset where competences were predetermined with respect to schooling, which in turn were predetermined with respect to the transition to the labour market.

\footnotetext{
${ }^{1}$ IALS is a survey collecting information on adult literacy in representative samples for some OECD countries, implemented in different years - 1994, 1996, 1998 - for different countries using a common questionnaire. The central element of the survey was the direct assessment of the literacy skills of respondents, but the background questionnaire also included detailed information on individual socio-demographic characteristics. In the public use version of the file, earnings were made available in categorical form, but the authors got access to the actual value. For more information, see http://www.statcan.gc.ca/dli-ild/data-donnees/ftp/ials-eiaa-eng.htm)

${ }^{2}$ They write "For example, a one standard deviation increase in test scores raises wages by 5.3 to 15.9 percent for men and 0.7 to 16.2 percent for women [our $\beta$ coefficient], while a one standard deviation increase in education raises wages by 4.8 to 16.8 percent for men and 6.8 to 26.6 percent for women. [our $\alpha$ coefficient].”
} 
Unfortunately, these dataset do exist in a few countries where longitudinal datasets were started several decades ago (US, UK, Sweden), but they hardly usable in a cross-country perspective. This has led us to pursue an alternative strategy of country/cohort analysis, matching aggregate inequality measures of competences, schooling and earnings based on the birth year of the relevant cohort. Bedard and Ferrall (2003), who study the correlation between the distribution of competences and the wage distribution of workers in the same birth cohorts, have already followed a similar strategy. They show that Lorenz curves for a cohort's wages always lay above the cohort's test score Lorenz curve. However, in their analysis, they do not take into account the mediating role played by educational attainment. Nor did they investigate the relevance of education policies, which, as we demonstrate, are highly influential on the distribution of education and incomes.

In the present paper we amend for this weakness by explicitly including inequality measures for schooling, and taking into account the potential endogeneity of these different dimensions of human capital. We also significantly extend the sample size, by considering repeated observations of the same cohort over different points of their life cycles. This strategy has pros and cons. The pros are represented by the possibility of potentially identifying causal effects of the human capital distribution onto the earnings distribution. The cons are working with aggregate data, which introduce possible confounding factors, which are only partially cured by including country/year fixed effects. In addition, aggregate data dramatically reduces the degrees of freedom, incurring in small sample problems when estimating. Overall, we deem that advantages overwhelm disadvantages, and that the present exercise may contribute to the advancement of our knowledge.

\section{Empirical strategy}

Let us start with a linearised version of equation (3), which reads as

$$
y_{i j}=a_{j}+\alpha_{j} h_{i}+\beta_{j} q_{i}+\gamma^{\prime} \mathbf{X}_{i j}+\varepsilon_{i j}
$$

The inequality observed in the distribution of $y$ will depend on the inequality in both quality $q$ and quantity $h$ of education, as well as on the distribution of any other observables in the vector $\mathbf{X}_{i}$ (like age, gender, ethnicity and so on) or unobservable component $\varepsilon$. Given the non-zero correlation between education and unobservables, it is generally impossible to decompose observed earnings inequality into separated contributions of underlying factors in a consistent way. ${ }^{3}$ The use

\footnotetext{
${ }^{3}$ As an illustrative example consider for example the inequality measure provided by the Gini concentration index. Neglect for simplicity the differences in observables described by $\mathbf{X}_{i}$ in equation (4), rewrite it as
} 
of decomposable inequality indices (like Theil) does not solve our problem, since they allow for between/within group decomposition without separating covarying variables (like quantity and quality of education).

Given the practical impossibility of modelling the structural relationship between the underlying distributions, we have resorted to the more modest strategy of studying the correlation among inequality measures, from which we can still deduce educational policy relevant propositions. By indicating with $I(x)$ a generic inequality indicator, we posit that an equivalent of equation (4) can be expressed as

$$
I(y)=\delta_{j}+\alpha I(h)+\beta I(q)+\omega_{j}
$$

where $\delta_{j}$ is a country/year fixed effect capturing any other sort of earnings inequality variation, while $\alpha$ and $\beta$ measure the correlation between (the distribution of) various dimensions of human capital (quantity and quality) and earnings (or income) inequality. If $h$ and/or $q$ are measured well in advance with respect to $y$ (in our case $h$ is measured at the end of schooling by the maximal educational attainment, $q$ is measured at the age of 14 , while $y$ is measured alternatively at the ages of 28, 44 and 59), one is tempted to provide a causal interpretation of statements like “a reduction in inequality in test scores is associated to a $\beta$-reduction in income inequality”. However, unobservable components at country level (like competitiveness, solidarity, ethnic fractionalisation and so on) may drive both dimension of inequality, leading to biased estimates of the relevant coefficients. Accounting for this possibility, we have resorted to an instrumental variable strategy to estimate equation (5) leading to

$$
\left\{\begin{array}{l}
I(h)=a_{j}+\mathbf{b}_{j}^{\prime} \mathbf{Z}_{j}+e_{j} \\
I(q)=c_{j}+\mathbf{d}_{j}^{\prime} \mathbf{Z}_{j}+g_{j} \\
I(y)=\delta_{j}+\alpha \hat{I}(h)+\beta \hat{I}(q)+\omega_{j}
\end{array}\right.
$$

$y_{i j}=a_{j}+\alpha_{j} h_{i}+\beta_{j} q_{i}+\varepsilon_{i j}$. The Gini index for a generic country/region $j$ can be computed according to $\operatorname{Gini}(y)=\frac{1}{2 \mu_{y}} \sum_{i} \sum_{k}\left|y_{i}-y_{k}\right|=\frac{1}{2 \mu_{y}} \sum_{i} \sum_{k}\left|\alpha\left(h_{i}-h_{k}\right)+\beta\left(q_{i}-q_{k}\right)+\left(\varepsilon_{i}-\varepsilon_{k}\right)\right|$. If one is available to accept that: $\left.i\right)$ the rank correlation between quality and quantity is one (namely students with the highest level of competences also obtain the highest educational attainments - in symbols $h_{i}>h_{k}$ iff $q_{i}>q_{k}$ ); ii) the unexpected component in earnings is small relative to the predictable component (in symbols $a+\alpha h_{i}+\beta q_{i}>\varepsilon_{i}, \forall i$ ), then it is possible to express the earnings inequality as $\operatorname{Gini}(y)=\alpha \frac{\mu_{h}}{\mu_{y}} \operatorname{Gini}(h)+\beta \frac{\mu_{q}}{\mu_{y}} \operatorname{Gini}(q)+$ residual . Thus only under implausible assumptions one can infer the inequality contribution of different component from the estimation of structural parameters in equation like (4). 
where the educational inequality measures in equation (5) are replaced by their projections obtained from a vector of (supposedly) exogenous variables pertaining reforms in the educational sectors affecting the relevant birth cohorts. We thus exploit both geographical and temporal variations in educational reforms by government to obtain unbiased estimates of the causal impact of educational inequality onto income inequality.

We have already suggested that an ideal dataset should measure quantity and quality of education at the age of exiting the educational system and earnings at a later age, following the entrance in the labour market. At the best of our knowledge, such a dataset does not exist with sufficient country coverage. For this reason, we have created a new dataset by combining data on measured inequality from students' tests with data on measured inequality on earnings of the same birth cohorts, gender and country.

Data on students' competences are obtained from three early surveys on mathematical competences of 14-year-old students conducted in past decades (FIMS 1964 was the first international survey testing mathematical competences of students born in or around 1950; SIMS 1980-82 tested students born in or around 1966 and TIMSS 1995 tested students born in or around 1981) ${ }^{4}$. We thus start with a population composed by three birth cohorts, born in 1950, 1966 and 1981 respectively, in countries that participated to the earliest students surveys. Data on schooling and labour market outcomes for the same cohorts can be obtained from representative samples of the corresponding population at later stages. However, if observed at the same point in time, we would be confusing cohorts and age effects (namely, older cohorts are characterised by higher level of competences and earnings inequalities). For this reason, we have resorted to two available datasets existing at European level and reporting data on earnings and incomes. The first one is the European Community Household Panel (ECHP), which started in $1994^{5}$ The second is the European Union Statistics on Income and Living Conditions (EUSILC), which started in 2004 and is updated annually. ${ }^{6}$ We selected the 1994 ECHP wave because it was the earliest available, while we resorted to the 2009 SILC wave because it was the first survey reporting consistent information on gross incomes for all participating countries. In table 1 we show the matching rule we followed

\footnotetext{
4 The FIMS (First International Mathematics Study) was conducted in 1964 to investigate the outcomes of school systems in cross-country perspective and repeated in 1980 when the SIMS (Second International Mathematics Study) took place. The third round was carried out in 1995 when the TIMSS (Trends in International Mathematics and Science Study) was administered. The data are accessible through the International Association for the Evaluation of Educational Achievement, IEA, at www.iea.nl.

${ }^{5}$ ECHP (European Community Household Panel) is a panel survey in which a sample of households and persons has been interviewed year after year, from 1994 to 2001 (8 waves), for the 14 European countries that were members of the EU in 1994. For more information see http://epp.eurostat.ec.europa.eu/portal/page/portal/microdata/echp.

6 EUSILC (European Union Statistics on Income and Living Conditions) is a collection of comparable multidimensional microdata covering EU countries plus Iceland and Norway. EUSILC is a project developed by EUROSTAT, run yearly since 2004 and including both cross-section and longitudinal surveys. For more information, see http://epp.eurostat.ec.europa.eu/portal/page/portal/microdata/eu_silc
} 
to construct our dataset. Take for example the students born in 1950 and tested in 1964 among others in six European countries (Belgium ${ }^{7}$, Finland, France, Germany, Netherlands and United Kingdom). The same birth cohort can be observed in the labour market around the age of 44 in 1994, thanks to ECHP (Finnish data not available, since Finland entered in 1996), and again at age 59, using the SILC data. The same logic applies to the other cohorts. ${ }^{8}$

Labour earnings data are obtained summing earnings from dependent employment (variable EARNINGS in ECHP or variable PY010G in SILC) and earnings from self-employment (variable SELFINCOME in ECHP or variable PY050G in SILC) and excluding cases of negative values. ${ }^{9}$ Individuals without earnings (housewives, unemployed, out of labour force) report zero values, but have been retained in our sample since labour market participation is potentially endogenous and definitely correlated with educational attainment and possession of competences. Thus any distribution of competences that encourages (discourages) labour market participation affects earnings distribution also via entering (leaving out) the relevant statistics. ${ }^{10}$

Data on years of education have been computed from maximum educational attainment according to ISCED classification (variable EDU in ECHP or variable PE040 in SILC) converted into years by using legal duration. ${ }^{11}$ Mathematics test scores, the only domain that has been tested since the 1964 FIMS, are calculated for the FIMS, SIMS and TIMSS data based on the number of correct answers to multiple-choice items. ${ }^{12}$ In order to partially account for gender composition and increase the degrees of freedom, we have computed these inequality measures separately for males and females.

\footnotetext{
${ }^{7}$ Belgian data are available for the Francophone and Flemish communities separately, but the same does not apply in the case of income data, therefore we were forced to consider Belgium as a unique entity.

${ }^{8}$ The cohort born in 1966 is aged 44 in 2010 and would require the use of 2010 SILC wave for consistency with the age of ECHP. After having checked that results are mostly unaffected when using either 2009 or 2010 waves, we have preferred to stick to the 2009 wave only, since there are slight changes between the two waves (for example in the coding of educational attainments). Results available from the authors.

${ }^{9}$ Notice that in the case of ECHP all values (except France) are net of taxes, while in the case of SILC we consistently make use of gross values. Negative earnings values exist in the case of self-employed, they have been converted into zeros in order to allow the calculation of inequality indices.

${ }^{10}$ By comparing $1^{\text {st }}$ and $4^{\text {th }}$ (and $2^{\text {nd }}$ and $5^{\text {th }}$ ) earning inequality mean values in table 2 one can grasp what is the potential size of distortion when including or excluding the non-labour force component.

${ }^{11}$ In the absence of an official source of legal duration possibly varying across different birth cohorts, we have obtained an estimate of median duration of studies by using the individual age of leaving school (variable AGEDU in ECHP or variable PE030 "Year when highest level of education was attained" in SILC), and then we have assigned 7 years for ISCED=1, 10 years for ISCED=2, 13 years for ISCED=3, 15 years for ISCED=4 and 18 years for ISCED=5 in SILC. Corresponding values are 8 for EDU $=1,12$ for EDU $=2$ and 17 for EDU $=3$ in ECHP.

12 Although since 1995, item response theory has been used to measure five plausible values of the true mathematics performance, for the earlier cohorts this was not possible. In TIMSS 1995 the correlation between our test score and the five plausible values is, in all five cases, 0.89 . For reasons of comparability we chose to operationalize math in the same way for all three cohorts.
} 
Table 1: Construction of the sample - matching rule

\begin{tabular}{|c|c|c|c|c|c|}
\hline Birth year & Aged 14 & Aged 28 & Aged 43-44 & Aged 59 & $\begin{array}{c}\text { matched } \\
\text { cohorts/countries }\end{array}$ \\
\hline 1950 & $\begin{array}{l}1964 \text { (from FIMS: } \\
\text { BE,FI,FR,DE,NL,UK) }\end{array}$ & $\begin{array}{c}1978 \\
\text { (data not available) }\end{array}$ & $\begin{array}{c}1994 \\
\text { (from ECHP1994: } \\
B E, F R, D E, N L, U K \text { ) }\end{array}$ & $\begin{array}{c}2009 \\
\text { (from SILC2009: } \\
\mathrm{BE}, \mathrm{FI}, \mathrm{FR}, \mathrm{DE}, \mathrm{NL}, \mathrm{UK} \text { ) }\end{array}$ & 11 \\
\hline 1966 & $\begin{array}{c}1980 \text { (from SIMS: } \\
\text { (BE,FI,FR,HU,NL,SE,UK) }\end{array}$ & $\begin{array}{c}1994 \\
\text { (from ECHP1994: } \\
\text { BE,FR,NL,UK) }\end{array}$ & $\begin{array}{c}2009 \\
\text { (from SILC2009: BE, } \\
\text { FI,FR,HU,NL,SE,UK) }\end{array}$ & & 11 \\
\hline 1981 & $\begin{array}{c}1995 \text { (from TIMS: } \\
\text { AT,BE,CZ,DK,FR,DE, } \\
\text { GR,HU,IE,IT,LV,NL,NO, } \\
\text { PT,SK,SI,ES,SE,UK) }\end{array}$ & $\begin{array}{c}2009 \\
\text { (from SILC2009: } \\
\text { AT,BE,CZ,DK,FR,DE, } \\
\text { GR,HU,IE,IT,LV,NL,NO, } \\
\text { PT,SK,SI,ES,SE,UK) }\end{array}$ & & & 19 \\
\hline
\end{tabular}

The country inequality measures (averaged over genders) are reported in table A1. Overall, we notice a higher inequality in older birth cohorts, with significant variations across countries, due to differences in educational histories and labour market institutions. ${ }^{13}$ Overall we possess an unbalanced panel covering 20 countries with 82 observations (41 country/cohort $\times 2$ genders). Figure 2 shows the plot of the relevant data, while table 2 reports the descriptive statistics for the relevant variables. From the graph we can observe that there is positive correlation between inequality in quantity and inequality in quality of education for the country/gender/cohort cell available (north-west panel). Both dimensions are also positively correlated with earnings inequality (computed over employees - north-east and south-west panels). In the last south-east panel we contrast earnings inequality for dependent employees and for total employment: the relationship between the twos is altered by the extent of self-employment, labour market participation (which is significantly varying across countries in accordance with gender), unemployment and early retirement (which are both computed at zero incomes).

\footnotetext{
${ }^{13}$ The high inequality recorded among the oldest birth cohort may be due to reduced labour market participation due to retirement (they are aged 59 at the time of the interview). The inclusion of pensions among earnings is prevented by the fact that they are grouped together in "social benefit" keeping separate track of "pension from private own plans".
} 
Table 2: Descriptive statistics

\begin{tabular}{|l|c|c|c|c|c|}
\hline Variable & Obs & Mean & $\begin{array}{c}\text { Std. } \\
\text { Dev. }\end{array}$ & Min & Max \\
\hline $\begin{array}{l}\text { Gini index on dependent employment gross earnings } \\
\text { (including non labour force with zero incomes) }\end{array}$ & 82 & 0.466 & 0.110 & 0.254 & 0.721 \\
\hline $\begin{array}{l}\text { Gini index on gross incomes } \\
\text { (including self-employed and non labour force - negative incomes set to 0) }\end{array}$ & 82 & 0.433 & 0.109 & 0.229 & 0.698 \\
\hline $\begin{array}{l}\text { Gini index on years of education } \\
\text { (computed from ISCED attainments) }\end{array}$ & 82 & 0.120 & 0.032 & 0.072 & 0.243 \\
\hline $\begin{array}{l}\text { Gini index on dependent employment gross earnings } \\
\text { (only positive values - excluding unemployed with zero incomes) }\end{array}$ & 82 & 0.310 & 0.061 & 0.193 & 0.452 \\
\hline $\begin{array}{l}\text { Gini index on gross incomes } \\
\text { (including self-employed but excluding non labour force - negative incomes set to 0) }\end{array}$ & 82 & 0.316 & 0.061 & 0.209 & 0.472 \\
\hline $\begin{array}{l}\text { Gini index on years of education } \\
\text { (computed from ISCED attainments - only population with positive incomes) }\end{array}$ & 82 & 0.115 & 0.029 & 0.074 & 0.216 \\
\hline Gini index on math test scores & 82 & 0.175 & 0.031 & 0.124 & 0.244 \\
\hline age of individuals (when interviewed about occupational status) & 82 & 37.04 & 11.40 & 28 & 59 \\
\hline reform on public pre-primary schooling & 82 & 0.508 & 0.445 & 0 & 1 \\
\hline compulsory education (start age) & 82 & 6.024 & 0.608 & 5 & 7 \\
\hline compulsory education (end age) & 82 & 15.415 & 1.440 & 12 & 18 \\
\hline tracking age & 82 & 13.476 & 2.263 & 10 & 16 \\
\hline introduction of standardised test & 82 & 0.341 & 0.451 & 0 & 1 \\
\hline reform on school accountability & 82 & 0.293 & 0.458 & 0 & 1 \\
\hline reform on school teacher autonomy & 82 & 0.549 & 0.494 & 0 & 1 \\
\hline reform of university access & 82 & 0.606 & 0.430 & 0 & 1 \\
\hline
\end{tabular}

Our general strategy, as illustrated in the previous section, is to regress earnings inequality measures onto corresponding inequality measures for years of schooling (proxy for quantity measured over the same population on which non negative/positive earnings are available) and for math test scores when the same cohort was around 14 years old (grade 8, proxy for quality measure). All other potentially confounding factors are controlled by means of corresponding dummies (gender, birth year, age, country and survey). 
Figure 2: Inequality in competences, years of schooling, gross labour earnings (from dependent employment and from total employment)
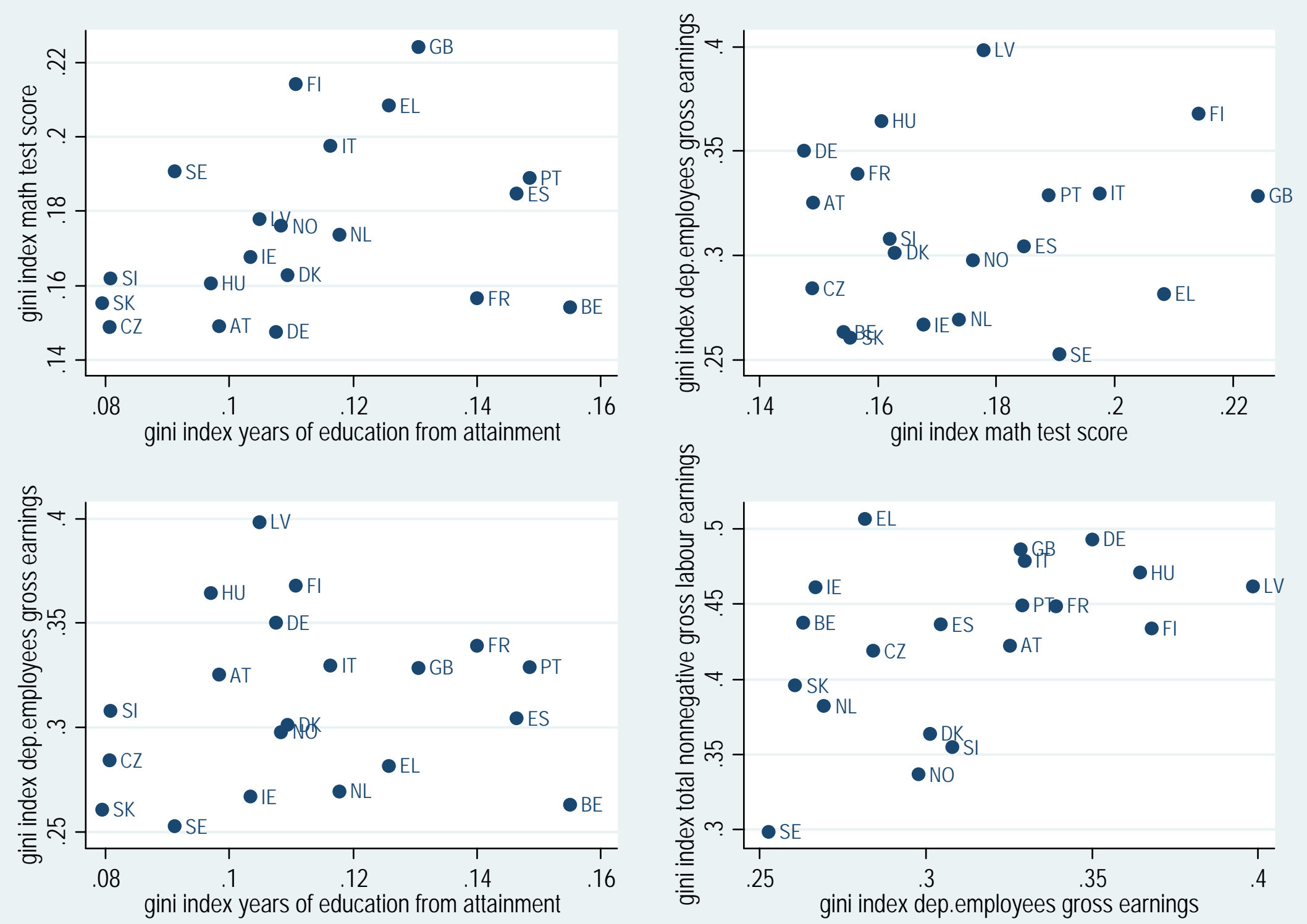
We do not have a priori about which is the most appropriate inequality measure to be used in this analysis, since each index captures different dimensions of the underlying distributions. In table 3 we propose three inequality measures, which are simply meant as descriptive correlation coefficients. We see that Gini concentration index and coefficient of variation exhibit statistically significant correlations among different dimensions of inequality, supporting the conjecture that inequality in quantity and inequality in quality of human capital are both positively associated with the observed earnings inequality (irrespective of whether we consider dependent employment incomes or total employment incomes). On the contrary, the standard deviation of logs does not conform to our expectation, suggesting that the log-linear functional form assumed in equation (3) does not provide a clear-cut decomposition that can be traced in the data. These correlations are robust against weighting the observation by the underlying population sizes. ${ }^{14}$

Table 3: Gross earnings and educational inequality - alternative inequality measures - OLS

\begin{tabular}{|c|c|c|c|c|c|c|}
\hline & $\begin{array}{c}1 \\
\text { Gini i } \\
\text { dep.empl. } \\
\text { earnings } \\
\text { (gross) }\end{array}$ & $\begin{array}{c}2 \\
\text { ndex } \\
\text { total } \\
\text { earnings } \\
\text { (gross) } \\
\end{array}$ & $\begin{array}{c}3 \\
\text { coeffic } \\
\text { vari } \\
\text { dep.empl. } \\
\text { earnings } \\
\text { (gross) } \\
\end{array}$ & $\begin{array}{l}\quad 4 \\
\text { ent of } \\
\text { tion } \\
\text { total } \\
\text { earnings } \\
\text { (gross) } \\
\end{array}$ & $\begin{array}{c}5 \\
\text { standard } \\
\text { of } 10 \\
\text { dep.empl. } \\
\text { earnings } \\
\text { (gross) } \\
\end{array}$ & $\begin{array}{l}\quad 6 \\
\text { deviation } \\
\text { gs } \\
\text { total } \\
\text { earnings } \\
\text { (gross) } \\
\end{array}$ \\
\hline $\begin{array}{l}\text { inequality in math test scores } \\
\text { inequality in years of education (from ISCED } \\
\text { attainments) } \\
\text { male component (share of) }\end{array}$ & $\begin{array}{c}0.899 \\
{[0.241]^{\star \star \star}} \\
0.833 \\
{[0.258]^{\star \star \star}} \\
-0.078 \\
{[0.017]^{\star \star \star}}\end{array}$ & $\begin{array}{c}0.683 \\
{[0.210]^{\star \star \star}} \\
0.881 \\
{[0.231]^{\star \star \star}} \\
-0.107 \\
{[0.015]^{\star \star \star}} \\
\end{array}$ & $\begin{array}{c}1.282 \\
{[0.388]^{\star \star *}} \\
1.227 \\
{[0.366]^{\star \star *}} \\
-0.161 \\
{[0.046]^{\star \star *}}\end{array}$ & $\begin{array}{c}1.100 \\
{[0.351]^{\star * \star}} \\
1.278 \\
{[0.361]^{\star * \star}} \\
-0.213 \\
{[0.042]^{\star \star *}} \\
\end{array}$ & $\begin{array}{c}0.464 \\
{[0.506]} \\
-0.263 \\
{[0.835]} \\
-0.115 \\
{[0.049]^{\star \star}} \\
\end{array}$ & $\begin{array}{c}0.325 \\
{[0.409]} \\
0.197 \\
{[0.747]} \\
-0.105 \\
{[0.043]^{\star \star}}\end{array}$ \\
\hline $\begin{array}{l}\text { Observations } \\
\text { Countries } \\
\text { R-squared }\end{array}$ & $\begin{array}{c}82 \\
20 \\
0.58\end{array}$ & $\begin{array}{c}82 \\
20 \\
0.64\end{array}$ & $\begin{array}{c}82 \\
20 \\
0.51\end{array}$ & $\begin{array}{c}82 \\
20 \\
0.56\end{array}$ & $\begin{array}{c}82 \\
20 \\
0.18\end{array}$ & $\begin{array}{c}82 \\
20 \\
0.21\end{array}$ \\
\hline
\end{tabular}

We have decided to focus on the Gini index as our relevant measure of inequality (columns (1) and (2) of table 3), since a linear relationship as equation (4) seems to fit the data better. ${ }^{15}$ In order to test the robustness of our results, in table 4 we present alternative specifications of the same relationship. In comparison to columns (1) and (2) of table 3, we start introducing country fixed effects, which raise significantly the estimated coefficients of inequalities in quantity and quality of human capital (see columns (1) and (2) of table 4). While we were already taking into account potential heteroscedasticity of residuals, we now consider the potential correlation between

\footnotetext{
${ }^{14}$ Again available from the authors upon request.

${ }^{15}$ In addition, the Gini index is a better measure for inequality when compared to the coefficient of variation, since it satisfies a preference for redistribution (Dalton-Pigou principle).
} 
inequality measures across genders in the same country: clustering errors weakens the statistical significance of inequality in test scores (columns (3) and (4) of table 4).

If we restrict the analysis to individuals with positive income values (namely the occupied labour force), part of the effect of educational inequalities is absorbed by the sample selection (especially among women and older birth cohorts). As we see from columns (5) and (6) of table 4, both inequality in test scores and inequality in educational attainment (measured across individuals with positive incomes) lose magnitude. This is an indication that whenever we measure earnings inequality we face a huge problem of self-selection into the labour market, that we are unable to properly model in this context. For this reason, we stick to the solution of including all the relevant population, imputing zero incomes when they are out of the labour market.

A final robustness check is obtained if we estimate our model separately for men and women (columns (7) to (10) in table 4). In this "heroic” case (remember that country/cohort/survey fixed effects are using 27 out of 41 degrees of freedom) we still keep some statistical significance for inequality in years of education, but we lose it for inequality in tests score.

Overall, the magnitude of the coefficient on inequality in test scores oscillates between 1 and 1.7, while the coefficient on inequality in years of education remains in the range of half of it, between 0.5 and 0.8 . In terms of elasticities (measured at sample means), earnings inequality measured by Gini concentration indices would exhibit an elasticity of 0.61-0.69 with respect to inequality in test scores and 0.21-0.22 with respect to inequality in years of education (computed from columns (3) and (4) of table 4).

Table 4: Gross earnings and educational inequality - Gini indices - OLS with country fixed effects

\begin{tabular}{|c|c|c|c|c|c|c|c|c|c|c|}
\hline & $\begin{array}{c}1 \\
\text { dep.empl. } \\
\text { earnings } \\
\text { robust se }\end{array}$ & $\begin{array}{c}2 \\
\text { total } \\
\text { earnings } \\
\text { robust se }\end{array}$ & $\begin{array}{c}3 \\
\text { dep.empl. } \\
\text { earnings } \\
\text { clustered se }\end{array}$ & $\begin{array}{c}4 \\
\text { total } \\
\text { earnings } \\
\text { clustered se }\end{array}$ & $\begin{array}{c}\quad 5 \\
\text { dep.empl. } \\
\text { earnings >0 } \\
\text { clustered se }\end{array}$ & $\begin{array}{c}6 \\
\text { total } \\
\text { earnings }>0 \\
\text { clustered se }\end{array}$ & $\begin{array}{c}7 \\
\text { male } \\
\text { dep.empl. } \\
\text { earnings } \\
\text { clustered }\end{array}$ & $\begin{array}{c}8 \\
\text { male total } \\
\text { earnings } \\
\text { clustered }\end{array}$ & $\begin{array}{c}9 \\
\text { female } \\
\text { dep.empl. } \\
\text { earnings } \\
\text { clustered se }\end{array}$ & $\begin{array}{l}10 \\
\text { female total } \\
\text { earnings } \\
\text { clustered se }\end{array}$ \\
\hline inequalit & $\begin{array}{c}1.631 \\
{[0.555]^{\star \star \star}}\end{array}$ & $\begin{array}{c}1.716 \\
{[0.546]^{\star \star \star}}\end{array}$ & $\begin{array}{c}1.631 \\
{[0.815]^{\star}}\end{array}$ & $\begin{array}{c}1.716 \\
{[0.817]^{\star \star}}\end{array}$ & $\begin{array}{c}1.084 \\
{[0.508]^{\star *}}\end{array}$ & $\begin{array}{c}1.079 \\
{[0.560]^{*}}\end{array}$ & $\begin{array}{c}1.152 \\
{[1.493]}\end{array}$ & $\begin{array}{c}1.615 \\
{[1.431]}\end{array}$ & $\begin{array}{c}1.386 \\
{[1.729]}\end{array}$ & $\begin{array}{c}1.517 \\
{[1.836]}\end{array}$ \\
\hline $\begin{array}{l}\text { inequality in years of education } \\
\text { (from isced attainments) } \\
\text { male component }\end{array}$ & $\begin{array}{c}0.849 \\
{[0.371]^{\star \star}} \\
-0.076 \\
{[0.012]^{\star \star \star}}\end{array}$ & $\begin{array}{c}0.825 \\
{[0.354]^{\star \star}} \\
-0.103 \\
{[0.012]^{\star \star \star}}\end{array}$ & $\begin{array}{c}0.849 \\
{[0.370]^{\star \star}} \\
-0.076 \\
{[0.013]^{\star \star *}}\end{array}$ & $\begin{array}{c}0.825 \\
{[0.377]^{\star *}} \\
-0.103 \\
{[0.012]^{\star \star *}}\end{array}$ & $\begin{array}{c}0.570 \\
{[0.153]^{\star \star \star}} \\
-0.037 \\
{[0.009]^{\star \star \star}}\end{array}$ & $\begin{array}{c}0.519 \\
{[0.194]^{\star \star}} \\
-0.033 \\
{[0.010]^{\star \star \star}}\end{array}$ & $\begin{array}{c}0.864 \\
{[0.705]}\end{array}$ & $\begin{array}{c}0.604 \\
{[0.611]}\end{array}$ & $\begin{array}{c}0.954 \\
{[0.516]^{*}}\end{array}$ & $\begin{array}{c}0.928 \\
{[0.600]}\end{array}$ \\
\hline $\begin{array}{l}\text { Observations } \\
\text { R-squared }\end{array}$ & $\begin{array}{c}82 \\
0.84\end{array}$ & $\begin{array}{c}82 \\
0.85\end{array}$ & $\begin{array}{c}82 \\
0.84\end{array}$ & $\begin{array}{c}82 \\
0.85\end{array}$ & $\begin{array}{c}82 \\
0.77\end{array}$ & $\begin{array}{c}82 \\
0.74\end{array}$ & $\begin{array}{c}41 \\
0.88\end{array}$ & $\begin{array}{c}41 \\
0.87\end{array}$ & $\begin{array}{c}41 \\
0.88\end{array}$ & $\begin{array}{c}41 \\
0.86\end{array}$ \\
\hline
\end{tabular}

col.1-2: robust standard errors in brackets - col.3-8: standard errors in brackets clustered by country - constant, country, age, birth year and survey controls included - * significant at 10\%; ** significant at 5\%; *** significant at $1 \%$

Despite the fact that schooling presumably ended before entrance in the labour market, and test scores were collected in years when the sampled population was 14 years old, still we cannot claim that inequalities in quantity and quality of human capital are causally correlated with inequalities in 
earnings and incomes. In order to strengthen the claim of causality, in table 5 we resort to instrumental variable estimation, which has the additional advantage of allowing the study of the impact of educational reforms on income inequality via their impact on inequality in quantity and quality of human capital. As measures of institutional design we exploit here the measures of educational reforms constructed by Braga et al. (2013) covering various stages of schooling. ${ }^{16}$

For ease of comparison in columns (1) and (2) of table 5 we have reproduced columns (3) and (4) of previous table 4. In columns (3) and (4) we present the corresponding IV estimations using a 2SLS estimator, while in columns (5) and (6) a GMM estimator is proposed. The bottom part of the table reports the first stage coefficients of the regression of the potentially endogenous variables (inequality in quantity and inequality in quality of education) onto the instruments represented by measured reforms. Starting with first stage coefficients signs and significance, we notice that inequality in years of education is reduced in countries that expanded pre-primary education or postponed the beginning age for compulsory education, while the school leaving age seems to have a counterintuitive positive correlation. ${ }^{17}$ Postponing the age at which students have to choose the secondary school track (wherever the educational system is stratified, like in Austria, Germany, Italy and the Netherlands) seem to increase both inequalities in schooling and test scores. ${ }^{18}$ On the contrary, strengthening the standardisation of national educational systems through the introduction of student testing is associated to a reduction of inequality. Finally, consistently with the results of Braga et al. (2013), increasing schools/teachers and universities autonomy reinforce their potential competitiveness, at the expenses of increased educational inequality. Similar patterns are observed in the case of competence inequality. The statistical significance of these effects relies on the method utilised to estimate the variance-covariance matrix: while educational reforms remain significant for test score inequality under both IV estimators, they tend to lose significance in the case of schooling inequality when passing to GMM method of estimation. Notice that all regressions control for country, birth year, age and survey fixed effects, so that reform impacts are identified by time variation within the countries and/or gender differential impacts within each country/year. Using the predicted inequalities in quantity and quality of human capital as regressors for income inequality, we observe that their coefficients lose statistical

\footnotetext{
${ }^{16}$ Braga et al (2013) claim that educational reforms may be effective in reducing inequality in schooling (where this is measured by the Atkinson index computed over years of education), while Bol and Van de Werfhorst (2013) have constructed measure of stratification of the secondary school systems (differentiation of students in different tracks, provision of vocationally specific skills and nationwide standardization of the educational system) showing in a crosssectional framework that the institutional design may be effective in shaping the distribution of student competences.

${ }^{17}$ Brunello et al. (2009) find that the expansion of duration of compulsory education (which in the present framework corresponds to the difference between entry and exit ages) reduces income inequality. According to the results of table 5 the opposite situation occurs, since expansion of compulsory education may be produced by either lowering the starting age or raising the leaving age, in both case yielding a positive impact on inequality in years of education.

${ }^{18}$ This latter effect contradicts standard findings in the literature on determinants of test scores(see for example Hanusheck and Woessman 2005) while it is consistent with the findings for inequality in years of education (Brunello and Checchi 2007)
} 
significance in comparison with OLS, while rising in magnitude in the case of schooling inequality. As long as educational reforms are reasonable exogenous instruments (which is formally tested as robustness check in Braga et al. 2013), these values can be interpreted as causal impacts. When compared to inequality in wages, the effects of educational inequalities on total earnings inequality tend to be more statistically significant. Looking at column (6), we may say that OLS estimates for test score inequality were upward biased, while the opposite situation occurs for schooling inequality, which now becomes more relevant. In terms of elasticities, the two dimensions of educational inequalities get closer ( 0.57 for test score inequality and 0.36 for schooling inequality, both computed from column (6) of table 5 at sample means).

Table 5: Gross earnings and educational inequality - Gini indices - OLS and IV estimates with educational reforms as instruments

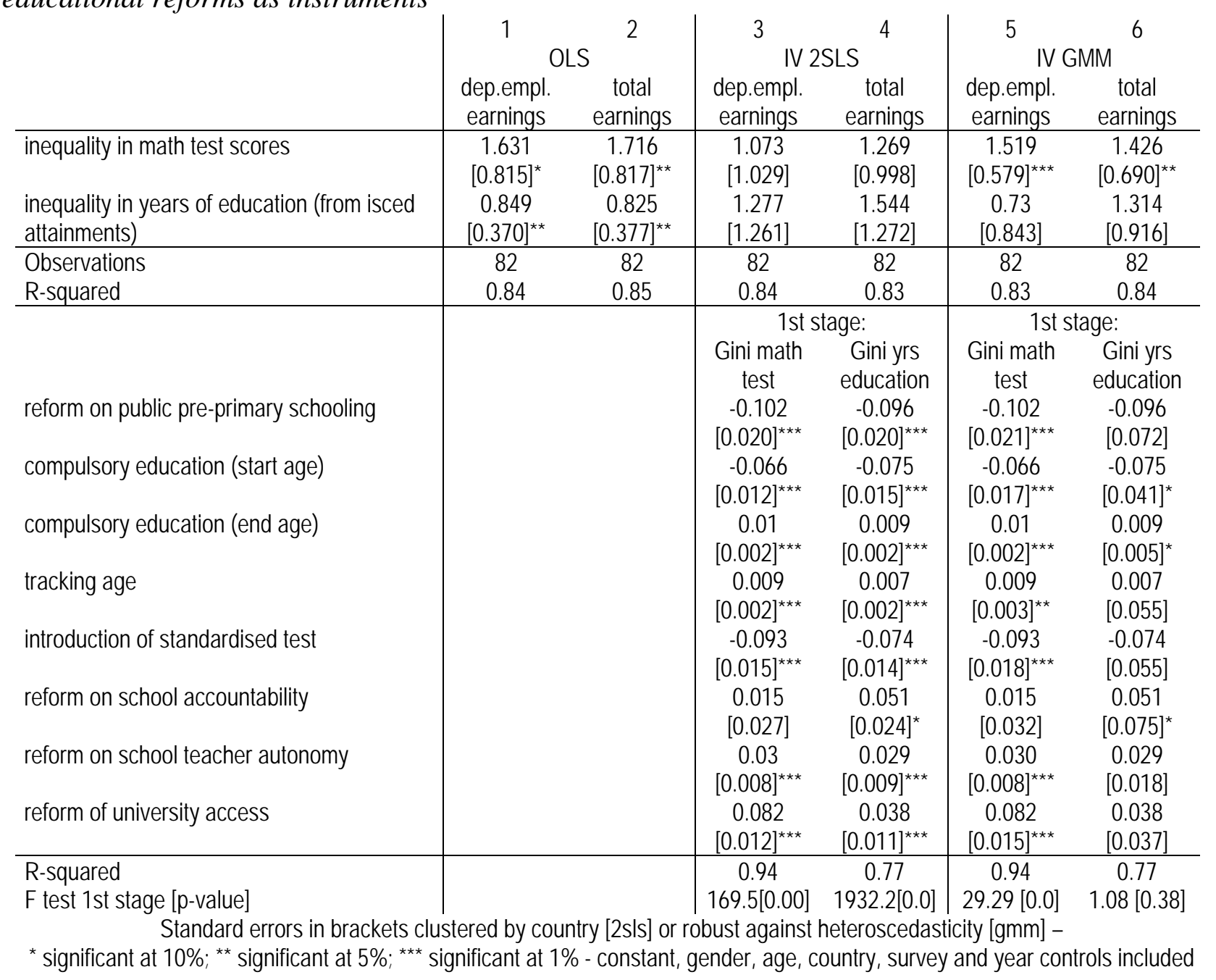

Table 6 summarises our policy implications in two ways, either by directly estimating a reduced form (where $I(y)$ is directly regressed onto the reform variables vector $\mathbf{Z}$ ) or by computing the overall impact of educational reforms onto earnings inequalities. Most of these effects are consistent with previous literature: reinforcing early (pre)schooling, delaying the beginning age for 
compulsory education, reinforcing educational standardisation by introducing standardised test scores, all reforms yield a reduction in income inequalities observed many years later in the labour market. On the contrary, increasing teachers' autonomy (in the selection of teaching contents), reinforcing school accountability and/or boosting university autonomy widen income differentials. According to the reduced form estimation, two additional reforms (increasing the years of education and delaying the tracking) come out statistically insignificant with respect to earnings inequalities. While we are not aware of comparable results in the literature, we can say that these insignificant results are partly at odds with received knowledge, at least with respect to educational achievements. $^{19}$

Table 6. Reduced form multipliers computed from table 5: effects of policies on income inequality

\begin{tabular}{|c|c|c|c|c|}
\hline & \multicolumn{2}{|c|}{$\begin{array}{l}\text { estimated from } \\
\text { reduced form }\end{array}$} & \multicolumn{2}{|c|}{$\begin{array}{l}\text { computed from columns } \\
\text { (5) and (6) of table } 5\end{array}$} \\
\hline & $\begin{array}{l}\text { Gini index } \\
\text { dependent } \\
\text { employment } \\
\text { earnings }\end{array}$ & $\begin{array}{c}\text { Gini index } \\
\text { on total } \\
\text { labour } \\
\text { earnings }\end{array}$ & $\begin{array}{l}\text { Gini index } \\
\text { dependent } \\
\text { employment } \\
\text { earnings }\end{array}$ & $\begin{array}{c}\text { Gini index } \\
\text { on total } \\
\text { labour } \\
\text { earnings }\end{array}$ \\
\hline reform on public pre-primary schooling & $\begin{array}{c}-0.346 \\
{[0.078]^{\star \star \star}}\end{array}$ & $\begin{array}{c}-0.407 \\
{[0.083]^{\star \star \star}}\end{array}$ & -0.225 & -0.272 \\
\hline compulsory education (start age) & $\begin{array}{c}-0.200 \\
{[0.053]^{\star \star \star}}\end{array}$ & $\begin{array}{c}-0.226 \\
{[0.056]^{\star \star \star}}\end{array}$ & -0.155 & -0.193 \\
\hline compulsory education (end age) & $\begin{array}{c}0.001 \\
{[0.007]}\end{array}$ & $\begin{array}{c}0.008 \\
{[0.008]}\end{array}$ & 0.022 & 0.026 \\
\hline tracking age & $\begin{array}{l}-0.007 \\
{[0.008]}\end{array}$ & $\begin{array}{l}-0.005 \\
{[0.008]}\end{array}$ & 0.019 & 0.022 \\
\hline introduction of standardised test & $\begin{array}{c}-0.178 \\
{[0.076]^{\star *}}\end{array}$ & $\begin{array}{c}-0.232 \\
{[0.088]^{\star *}}\end{array}$ & -0.195 & -0.230 \\
\hline reform on school accountability & $\begin{array}{c}0.176 \\
{[0.099]^{*}}\end{array}$ & $\begin{array}{c}0.232 \\
{[0.102]^{\star \star}}\end{array}$ & 0.060 & 0.088 \\
\hline reform on school teacher autonomy & $\begin{array}{c}0.100 \\
{[0.031]^{\star \star \star}}\end{array}$ & $\begin{array}{c}0.125 \\
{[0.032]^{\star \star \star}}\end{array}$ & 0.067 & 0.081 \\
\hline reform of university access & $\begin{array}{c}0.077 \\
{[0.052]}\end{array}$ & $\begin{array}{c}0.104 \\
{[0.055]^{\star}}\end{array}$ & 0.152 & 0.167 \\
\hline $\begin{array}{l}\text { Observations } \\
\text { R-squared }\end{array}$ & $\begin{array}{c}82 \\
0.83\end{array}$ & $\begin{array}{c}82 \\
0.85\end{array}$ & & \\
\hline
\end{tabular}

In order to appreciate the magnitude of these impacts, in figure 3 we have plotted the reduced form coefficients (column 1 of table 6) multiplied by one standard deviation change of the reform variables. Results are strongly consistent with the findings of Braga et al. (2013): some reforms

\footnotetext{
${ }^{19}$ Brunello et al. (2009) for example show that compulsory school reforms significantly affect educational attainment, especially among individuals belonging to the lowest quantiles of the distribution of ability. They also provide evidence that additional education reduces conditional wage inequality. Brunello and Checchi (2007) have shown that rising the tracking age lowers the average years of education but reduces the inequality in adult competences. On the contrary Hanusheck and Woessman (2005) provide evidence that rising the tracking age lowers the average level of competences and increases its dispersion. Finally Bol and Van de Werfhorst (2013) have shown that rising tracking age and introducing central examination reduces the inequality of opportunities, because it lowers the gradient of parental background.
} 
(that they call "inclusive”) are effective in reducing earnings inequality, the strongest impact exerted by the expansion of public pre-primary education; other reforms (that they termed "selective" because they increase the degree of competition among educational institutions) are effective in raising income inequality, via increased variability in both dimensions of human capital in the relevant population. Some of these effects are weak and not statistically different from zero (like tracking age, the variation in compulsory education end age or the university access), but the remaining ones have relevant magnitudes, since the measure units of the horizontal axis of figure 3 are to be interpreted as Gini points.

Figure 3 - Income inequality impact of educational reforms

\section{Impact on Gini index on dependent employment earnings of one standard deviation increase in reform variables}

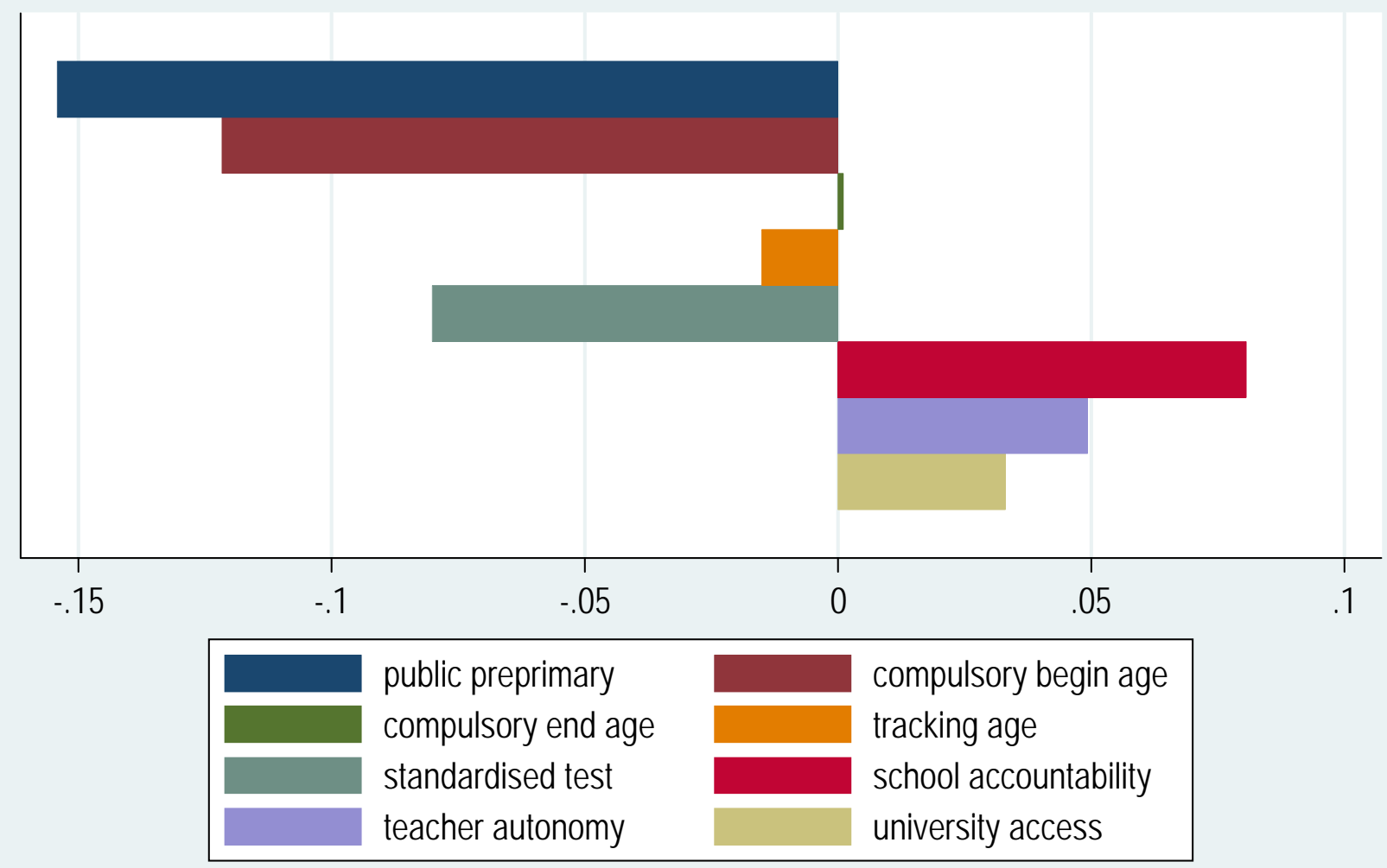

Overall, our results do not reject our conjecture that inequality in education affects inequality in earnings along two dimensions, quality and quantity. In addition, we have also shown that inequality in quality (as measured by student test scores) and inequality in quantity (as measured by years of schooling) respond to educational policies. 


\section{Conclusions and discussion}

We studied the relationship between educational policies, educational distributions and income inequality. Adopting a framework in which educational distributions have both a qualitative and a quantitative dimension, with quality referring to student performance on standardized tests, and quantity referring to the attained level of education, we examined whether educational reforms affect education, and, through education, the distribution of incomes in society. By combining four different sources of cross-nationally comparative data (international student assessments, educational attainment, income distributions, and a newly collected data set on educational reforms), we were able to examine data for cohorts born between 1950 and 1981 . Our results indicated that educational reforms do have an effect on the distribution of the quality and the quantity of education. The distribution of skills and attainment is furthermore related to the level of income/earnings inequality in a society. Consequently, educational policies have an impact on the income and earnings distributions. These findings are supportive of the idea that educational policies can be part of an effective strategy to address income and earnings distributions. 


\section{References}

Acemoglu, Daron and David Autor. 2011. Skills, Tasks and Technologies: Implications for Employment and Earning. in Orley Ashenfelter and David Card (eds) Handbook of labor economics - vol.4b. Amsterdam: Elsevier North Holland: 1043-1171

Arum, R., and Shavit, Y. (1995). Secondary Vocational Education and the Transition from School to Work. Sociology of Education, 68(July), 187-204.

Bedard, Kelly and Christopher Ferrall. 2003. Wage and test score dispersion: some international evidence. Economics of Education Review 22: 31-43

Blau, Francine and Kahn, Lawrence. 2005. Do cognitive test scores explain higher US wage inequality. Review of Economics and Statistics, 87(1): 184-193.

Bol, Thijs, en Van de Werfhorst, Herman G. (2013). Educational Systems and the Trade-off Between Labor Market Allocation and Equality of Educational Opportunity. Comparative Education Review, 57(2): 285-308.

Braga M., Checchi D. and Meschi E. 2013. Institutional Reforms and Educational Attainment in Europe: A long run perspective. Economic Policy 73: 45-100

Brunello, G., and Checchi, D. (2007). Does school tracking affect equality of opportunity? New international evidence. Economic Policy, 22(52), 781-861.

Brunello, G., Fort, M. and Weber, G. 2009. Changes in Compulsory Schooling, Education and the Distribution of Wages in Europe, Economic Journal, 119(536): 516-539.

Buchmann, C., and Dalton, B. (2002). Interpersonal Influences and Educational Aspirations in 12 Countries: The Importance of Institutional Context. Sociology of Education, 75(2), 99-122.

Buchmann, C., and Park, H. (2009). Stratification and the formation of expectations in highly differentiated educational systems. Research in Social Stratification and Mobility, 27(4), 245-267.

Card, David. 1999. The causal effect of education on earnings. in Ashenfelter, O. and D.Card (eds). Handbook of Labor Economics - vol.3. Amsterdam: Elsevier North Holland: 1801-1863

Cobb-Clark, D. A., Sinning, M., and Stillman, S. (2012). Migrant Youths’ Educational Achievement The Role of Institutions. The ANNALS of the American Academy of Political and Social Science, 643(1), 18-45.

De Gregorio, J. and Lee, J. (2002). Education and Income Inequality: New Evidence From CrossCountry Data. Review of Income and Wealth, 48(3), 395-416.

Dronkers, J., and De Heus, M. (2010). Negative selectivity of Europe's guest-worker immigration? The educational achievement of children of immigrants compared with native children in their origin countries. In E. De Corte and J. Fenstad (Red.), From Information to Knowledge; from Knowledge to Wisedom: Challenges and Changes facing Higher Education in the Digital Age (pp. 89-104). London: Portland Press. Geraadpleegd van http://mpra.ub.uni-muenchen.de/22213/

Duru-Bellat, Marie and Bruno Suchaut. 2005. L'approche sociologique des effets du contexte scolaire : Méthodes et difficultés. Revue internationale de psychologie sociale 18:5-42.

Entorf, H., and Lauk, M. (2008). Peer effects, social multipliers and migrants at school: an international comparison. Journal of Ethnic and Migration Studies, 34(4), 633-654.

Freeman, Richard and Ronald Schettkat. 2001. Skill Compression, Wage Differentials and Employment: Germany vs. the US. Oxford Economic Papers, 53:3, pages 582-603..

Galor, Oded. 2012 Inequality, Human Capital Formation and the Process of Development. in Eric A. Hanushek, Stephen Machin and Ludger Woessmann (eds). Handbook of the Economics of Education - vol.4c Amsterdam: Elsevier North Holland: 441-493

Goldin, Claudia D., \& Katz, Lawrence F. (2009). The Race between Education and Technology. Harvard University Press.Green, D. and Riddell, W. 2003. Literacy and earnings: an investigation of the interaction of cognitive and unobserved skills in earnings generation. Labour Economics 100(2): 165-84. 
Hanushek, Eric A., and Woessmann, Ludger. 2005. Does Educational Tracking Affect Performance and Inequality? Differences-in-Differences Evidence Across Countries. Economic Journal 116: C63-C76.

Hanushek, Eric A., and Woessmann, Ludger. (2011). The Economics of International Differences in Educational Achievement. In E. A. Hanushek, S. Machin, and L. Woessmann (Red.), Handbooks of the Economics of Education (Vol. 3, pp. 89-200). The Netherlands: NorthHolland/Elsevier.

Heckman, James, Lance J. Lochner and Petra E. Todd. 2006. Earnings Functions, Rates of Return and Treatment Effects: The Mincer Equation and Beyond. in E.Hanushek and F.Welch (eds). Handbook of the Economics of Education - vol.4a. Amsterdam: Elsevier North Holland: 307-458

Horn Daniel. 2009. Age of Selection Counts: A Cross-country Analysis of Educational Institutions. Educational Research and Evaluation 15: 343-366.

Huang, M.-H. (2009). Classroom Homogeneity and the Distribution of Student Math Performance: A Country-Level Fixed-Effects Analysis. Social Science Research, 38, 781-791.

Husén, T. (1973). The Standard of the Elite: Some Findings from the IEA International Survey in Mathematics and Science. Acta Sociologica, 16(4), 305-323.

Kerckhoff, A. C. (1977). The Realism of Educational Ambitions in England and the United States. American Sociological Review, 42(4), 563-571

Kerckhoff, A. C. (1995). Institutional Arrangements and Stratification Processes in Industrial Societies. Annual Review of Sociology, 15, 323-347.

Koçer, R. G., and Van de Werfhorst, H. G. (2012). Does education affect opinions on economic inequality? A joint mean and dispersion analysis. Acta Sociologica, 55(3), 251-272.

Marks, G. N. (2005). Cross-national differences and accounting for social class inequalities in education. International Sociology, 20(4), 483-505.

Meyers, M. K., \& Gornick, J. C. (2003). Public or Private Responsibility? Early Childhood Education and Care, Inequality, and the Welfare State. Journal of Comparative Family Studies, 34(3), 379-411.

Micklewright, J., and Schnepf, S. V. (2007). Inequality of learning in industrialized countries. In S. P. Jenkins and J. Micklewright (Red.), Inequality and Poverty Re-examined (pp. 129-145). Oxford: Oxford University Press.

Montt, G. (2011). Cross-national Differences in Educational Achievement Inequality. Sociology of Education, 84(1), 49-68.

Peracchi, Franco. 2006. Educational Wage Premia and the Distribution of Earnings: An International Perspective. in E.Hanushek and F.Welch (eds). Handbook of the Economics of Education - vol.4a. Amsterdam: Elsevier North Holland: 189-254

Pfeffer, F. T. (2008). Persistent Inequality in Educational Attainment and its Institutional Context. European Sociological Review, 24(5), 543-565.

Rodríguez-Pose, A., and Tselios, V. (2009). Education and Income Inequality in the Regions of the European Union. Journal of Regional Science, 49(3), 411-437.

Schüz, G., Ursprung, H. and Woessmann, L. 2008. Education Policy and Equality of Opportunity. Kyklos, vol. 61(2): 279-308.

Shavit, Y., and Müller, W. (2000). Vocational secondary education. European Societies, 2(1), 2950.

Solga, H. (2014). Education, economic inequality and the promises of the social investment state. Socio-Economic Review, 12(2), 269-297.

Vandenberge, V. (2006). Achievement effectiveness and equity: the role of tracking, grade repetition and inter-school segregation. Applied Economics Letters, 13(11), 685-693.

Van de Werfhorst, Herman G. and Jonathan J.B. Mijs. 2010. Achievement Inequality and the Institutional Structure of Educational Systems: A Comparative Perspective. Annual Review of Sociology, 36, 407-428. 
Wössmann, L. 2005. The effect heterogeneity of central examinations: evidence from TIMSS, TIMSS-Repeat and PISA. Education Economics 13(2): 143-169. 
Table A1 - Inequality in earnings and educational attainment - averages across gender and age cohorts

$1^{\text {st }}$ number: Gini index on gross total labour earnings of employed -

$2^{\text {nd }}$ number: Gini index on years of education of the same population (from maximal educational attainment) $3^{\text {rd }}$ number: Gini index on math test score -

$4^{\text {th }}$ number: individuals with positive incomes

$5^{\text {th }}$ number: observations available in the sample

\begin{tabular}{|c|c|c|c|c|}
\hline & \multicolumn{3}{|c|}{ birth year } & \multirow[b]{2}{*}{ Total } \\
\hline & 1950 & 1966 & 1981 & \\
\hline \multirow[t]{5}{*}{ Austria } & & & 0.32 & 0.32 \\
\hline & & & 0.10 & 0.10 \\
\hline & & & 0.15 & 0.15 \\
\hline & & & 134 & 134 \\
\hline & & & 2 & 2 \\
\hline \multirow[t]{5}{*}{ Belgium } & 0.32 & 0.25 & 0.21 & 0.27 \\
\hline & 0.15 & 0.12 & 0.10 & 0.13 \\
\hline & 0.17 & 0.15 & 0.12 & 0.15 \\
\hline & 202 & 282 & 136 & 620 \\
\hline & 4 & 4 & 2 & 10 \\
\hline \multirow[t]{5}{*}{ Czech Republic } & & & 0.30 & 0.30 \\
\hline & & & 0.08 & 0.08 \\
\hline & & & 0.15 & 0.15 \\
\hline & & & 188 & 188 \\
\hline & & & 2 & 2 \\
\hline \multirow[t]{5}{*}{ Denmark } & & & 0.30 & 0.30 \\
\hline & & & 0.11 & 0.11 \\
\hline & & & 0.16 & 0.16 \\
\hline & & & 97 & 97 \\
\hline & & & 2 & 2 \\
\hline \multirow[t]{5}{*}{ Finland } & 0.37 & 0.35 & & 0.36 \\
\hline & 0.12 & 0.10 & & 0.11 \\
\hline & 0.21 & 0.22 & & 0.21 \\
\hline & 363 & 361 & & 724 \\
\hline & 2 & 2 & & 4 \\
\hline \multirow[t]{5}{*}{ France } & 0.41 & 0.33 & 0.26 & 0.35 \\
\hline & 0.17 & 0.12 & 0.10 & 0.14 \\
\hline & 0.18 & 0.15 & 0.14 & 0.16 \\
\hline & 456 & 545 & 246 & 1247 \\
\hline & 4 & 4 & 2 & 10 \\
\hline \multirow[t]{5}{*}{ Germany } & 0.35 & & 0.36 & 0.35 \\
\hline & 0.12 & & 0.09 & 0.11 \\
\hline & 0.14 & & 0.16 & 0.15 \\
\hline & 638 & & 185 & 823 \\
\hline & 4 & & 2 & 6 \\
\hline \multirow[t]{5}{*}{ Greece } & & & 0.31 & 0.31 \\
\hline & & & 0.11 & 0.11 \\
\hline & & & 0.21 & 0.21 \\
\hline & & & 168 & 168 \\
\hline & & & 2 & 2 \\
\hline \multirow[t]{5}{*}{ Hungary } & & 0.35 & 0.37 & 0.36 \\
\hline & & 0.09 & 0.09 & 0.09 \\
\hline & & 0.16 & 0.16 & 0.16 \\
\hline & & 266 & 234 & 500 \\
\hline & & 2 & 2 & 4 \\
\hline \multirow[t]{5}{*}{ Ireland } & & & 0.26 & 0.26 \\
\hline & & & 0.10 & 0.10 \\
\hline & & & 0.17 & 0.17 \\
\hline & & & 85 & 85 \\
\hline & & & 2 & 2 \\
\hline
\end{tabular}




\begin{tabular}{|c|c|c|c|c|}
\hline \multirow[t]{5}{*}{ Italy } & & & 0.33 & 0.33 \\
\hline & & & 0.11 & 0.11 \\
\hline & & & 0.20 & 0.20 \\
\hline & & & 421 & 421 \\
\hline & & & 2 & 2 \\
\hline \multirow[t]{5}{*}{ Latvia } & & & 0.39 & 0.39 \\
\hline & & & 0.10 & 0.10 \\
\hline & & & 0.18 & 0.18 \\
\hline & & & 134 & 134 \\
\hline & & & 2 & 2 \\
\hline \multirow[t]{5}{*}{ Netherlands } & 0.32 & 0.28 & 0.22 & 0.28 \\
\hline & 0.12 & 0.11 & 0.10 & 0.11 \\
\hline & 0.18 & 0.18 & 0.14 & 0.17 \\
\hline & 406 & 482 & 196 & 1084 \\
\hline & 4 & 4 & 2 & 10 \\
\hline \multirow[t]{5}{*}{ Norway } & & & 0.30 & 0.30 \\
\hline & & & 0.11 & 0.11 \\
\hline & & & 0.18 & 0.18 \\
\hline & & & 107 & 107 \\
\hline & & & 2 & 2 \\
\hline \multirow{5}{*}{ Portugal } & & & 0.33 & 0.33 \\
\hline & & & 0.15 & 0.15 \\
\hline & & & 0.19 & 0.19 \\
\hline & & & 106 & 106 \\
\hline & & & 2 & 2 \\
\hline \multirow[t]{5}{*}{ Slovak Republic } & & & 0.26 & 0.26 \\
\hline & & & 0.08 & 0.08 \\
\hline & & & 0.16 & 0.16 \\
\hline & & & 198 & 198 \\
\hline & & & 2 & 2 \\
\hline \multirow[t]{5}{*}{ Slovenia } & & & 0.30 & 0.30 \\
\hline & & & 0.08 & 0.08 \\
\hline & & & 0.16 & 0.16 \\
\hline & & & 420 & 420 \\
\hline & & & 2 & 2 \\
\hline \multirow[t]{5}{*}{ Spain } & & & 0.31 & 0.31 \\
\hline & & & 0.14 & 0.14 \\
\hline & & & 0.18 & 0.18 \\
\hline & & & 361 & 361 \\
\hline & & & 2 & 2 \\
\hline \multirow[t]{5}{*}{ Sweden } & & 0.23 & 0.28 & 0.25 \\
\hline & & 0.09 & 0.09 & 0.09 \\
\hline & & 0.22 & 0.16 & 0.19 \\
\hline & & 260 & 155 & 415 \\
\hline & & 2 & 2 & 4 \\
\hline \multirow[t]{5}{*}{ United Kingdom } & 0.37 & 0.36 & 0.29 & 0.35 \\
\hline & 0.14 & 0.13 & 0.09 & 0.13 \\
\hline & 0.23 & 0.24 & 0.18 & 0.22 \\
\hline & 387 & 554 & 130 & 1071 \\
\hline & 4 & 4 & 2 & 10 \\
\hline \multirow[t]{5}{*}{ Total } & 0.35 & 0.3 & 0.3 & 0.32 \\
\hline & 0.14 & 0.11 & 0.1 & 0.11 \\
\hline & 0.18 & 0.19 & 0.17 & 0.18 \\
\hline & 2452 & 2750 & 3701 & 8903 \\
\hline & 22 & 22 & 38 & 82 \\
\hline
\end{tabular}

